\title{
Recent Methodological Approaches to Human Microbiome
}

\author{
Jin-Woo Bae \\ Department of Biology, Kyung Hee University, Seoul, Korea
}

\begin{abstract}
Human body is one of the most complex and diverse microbial ecosystem in which various microbes are living together with their hosts. Starting with Louis Pasteur's postulation that human health is dependent on gut-resident microbiota, microbes in the gastrointestinal tract have been studied using culture-based techniques. Cultivation has the great advantage that isolates can be recovered and used to further studies for their ability to utilize different substrates and other physiological properties. However, cultivation method is very labor-intensive and can not reveal representative microbial diversity of human intestinal tract. Only small fraction of the microbes residing in human intestine can be cultured and majority of intestinal microbes (approximately $60 \sim 70 \%$ of intestinal microbes) can not be come into view with currently available cultivation techniques. To avoid reliance on cultivation, many culture-independent molecular methods have been developed to analysis environmental microbes and our understanding of complex microbial communities has been greatly increased by molecular methods in recent decades. These culture-independent methods are mainly based on the use of microbial DNA sequences. Among prokaryotic DNAs targeted by molecular analysis, approximately $1.5 \mathrm{~kb}$ long $16 \mathrm{~S}$ ribosomal DNA gene that encodes part of the small subunit (SSU) of ribosome is often used for analysis of microbial diversity. Molecular techniques introduced in microbial ecology have made it possible to study the composition of intestinal flora in a culture-independent way based on the detection of SSU rDNA.
\end{abstract}

Key Words: Intestinal microbiota, Culture-dependent method, Culture-independent method

\author{
서 론 \\ 사람의 몸에는 100 조(兆)개 이상의 미생물이 살고 있 \\ 으며, 이들 미생물이 지니는 유전자의 수는 우리 몸의 전 \\ 체 유전자 수보다 최소한 100 배 이상 많은 것으로 추정 \\ 하고 있다. 특히 사람의 대장은 영양분이 풍부하며, $10^{11}$ \\ $10^{12} \mathrm{cells} / \mathrm{ml}$ 에 달하는 미생물이 존재한다 (1). 이러한 장 \\ 내 미생물은 음식물 소화에 직접적으로 관여하여 사람 \\ 조직의 에너지 대사를 조절한다. 따라서 장내 미생물 군 \\ 집의 변화는 비만, 장염, 면역조절 등에 중요한 역할을 \\ 한다는 연구들이 끊임없이 나오고 있다. 이와 같은 연구 \\ Received: February 6, 2011/ Revised: February 14, 2011 \\ Accepted: February 19, 2011 \\ *Corresponding author: Jin-Woo Bae. Department of Biology, Kyung Hee \\ University, Seoul, Korea. \\ Phone: +82-2-961-2312, Fax: +82-2-961-0244 \\ e-mail: baejw@khu.ac.kr
}

결과들은 사람 건강에 대한 연구가 장내 미생물로 연관 되는 이유이기도 하다.

장내 미생물에 대한 전통적인 연구 방법은 배양법을 이용한 미생물의 표현형적 특징에 국한되어 진행되었다. 이와 같은 연구 방법은 장내 미생물 연구의 기본 토대를 구축하였지만, 그 결과 장내 미생물 연구에 대한 편중된 결과를 나타내기도 하였다. 이런 한계점을 극복하기 위해 미생물 $16 \mathrm{~S} \mathrm{rRNA}$ 의 염기서열의 분석 방법이 도입되었다. 이어 fluorescence in situ hybridization (FISH), Denaturing Gradient Gel Electrophoresis (DGGE), Temperature Gradient Gel Electrophoresis (TGGE), Quantitative PCR, Terminal Restriction Fragment Length Polymorphism (T-RFLP), 16S rRNA gene cloning, plasmid profiling 등이 장내 미생물의 다 양성을 연구하는 데 적용되고 있다 (2). 최근에는 게놈과 메타게놈 연구에 'omics' 기술이 도입되었고 next generation sequencing (NGS)과 DNA microarray가 장내 미생물에 대 한 연구에 널리 적용되고 있음을 주목할 필요가 있다. 이 
런 방법은 배양에 기초한 방법이나 small-subunit rRNA 염기서열분석 방법에 의한 기존 연구보다 환경 미생물 군집의 다양성과 개체밀도에 대해 더 많은 정보를 얻을 수 있게 해주었다. 본 종설에서는 장내 환경에서 특정 미 생물 혹은 다양한 미생물을 검출하고 분석하기 위한 분 자방법론적 기술에 대한 특징과 적용 사례 등을 고찰하 고자 한다.

\section{본 론}

1. 전통적 방법의 장내 미생물 군집 분석: 배지를 이 용한 배양법

1980년대 후반까지 미생물의 다양성을 연구하기 위해 대부분의 미생물 학자들은 선택 배지를 이용한 배양 방 법과 현미경을 이용한 미생물의 형태를 관찰하는 방법을 사용하여 왔다. 배양 배지는 미생물을 분리하는데 사용되 기 때문에 사람 장내와 비슷한 $\mathrm{pH}$ 와 그 안에서 이용 가 능한 영양분과 같은 환경적 요인을 만족시켜야만 한다. 따라서 수적으로 우세한 미생물만 분리해 내는 편중된 결과가 나올 수 있다. 또한 형태를 바탕으로 미생물 분류 에는 한계가 있으며, 현미경으로 관찰 가능한 대부분의
미생물들도 이러한 접근 방법으로는 배양 가능하지 않다 는 어려움이 있다. 이와 같은 단점을 보완하기 위해 아래 와 같은 다양한 분자방법론이 채택되었다.

\section{2. 분자방법론적 접근에의 장내 미생물 군집 분석}

지난 30 년간 미생물 다양성을 연구하는데 있어서 분자 방법론적 접근은 극적인 변화를 가져왔다. 예를 들어, 발 견되지 않은 미생물들은 배양하기 어렵거나(난배양성) 현실적으로 배양이 되지 않는(비배양성) 미생물이 대부 분일 것이다. 최근 이들을 인공적으로 분리, 배양하지 않 고도 직접 이용하고자 하는 기술이 개발되었다(Table 1). 즉, 환경에 존재하는 미생물을 직접 배양하지 않고, 그들 의 유전체(metagenome)를 직접 추출하여 자연계의 미생 물 생태계를 조사하거나 활용하려는 메타게놈 라이브러 리 구축 및 스크리닝 기술이 선진 각국에서 개발되었다. 따라서 자연계의 난배양성 또는 비배양성 미생물을 이용 할 수 있는 길이 열렸다고 할 수 있다. 현재 메타게놈 기 술을 이용한 연구를 통해서 산업적으로 유용하거나 가치 가 높은 신규 유용물질을 개발하려는 연구가 활발히 진 행되고 있다. 특히 microarray와 next generation sequencing (NGS)과 같은 기술의 도입으로 다양한 환경 시료들로부

Table 1. Notable features of molecular methods for studying the intestinal microbiota

\begin{tabular}{|c|c|c|}
\hline Methods & Advantage & Limitation \\
\hline Cultivation & $\begin{array}{l}\text { Capable of isolation of microorganisms, physiological } \\
\text { and biochemical test of isolates }\end{array}$ & $\begin{array}{l}\text { Lots of time and effort required } \\
\text { Deficient reproducibility } \\
\text { Difficult to isolate uncultivated microorganisms }\end{array}$ \\
\hline DGGE & $\begin{array}{l}\text { Monitoring of microbial community change } \\
\text { Comparison analysis of microbial community in various } \\
\text { samples }\end{array}$ & $\begin{array}{l}\text { Inaccurate quantitative analysis due to PCR biases } \\
\text { Requirement of sequencing to identify each band. } \\
\text { Detectable only for dominant microorganisms }\end{array}$ \\
\hline FISH & Microbial detection and quantification in situ & $\begin{array}{l}\text { Low specificity of designed probe } \\
\text { Difficult to detect all of targeted microorganisms }\end{array}$ \\
\hline $\begin{array}{l}\text { Flow } \\
\text { cytometry }\end{array}$ & $\begin{array}{l}\text { Detection and separation of targeted microorganisms } \\
\text { Obtain ability of uncultured microbial genomes }\end{array}$ & $\begin{array}{l}\text { The same shortcomings as FISH } \\
\text { Incorrect cytometry }\end{array}$ \\
\hline Q-PCR & Quantitative analysis of specific microorganisms & $\begin{array}{l}\text { Very low-throughput } \\
\text { Need of each different primer set and independent } \\
\text { experiment for targeted microorganisms }\end{array}$ \\
\hline Microarray & $\begin{array}{l}\text { Very high-throughput } \\
\text { Analysis of functional gene as well as 16S rRNA gene }\end{array}$ & $\begin{array}{l}\text { Difficult to design specific probe } \\
\text { High cost } \\
\text { Low sensitivity than Q-PCR with environmental sample }\end{array}$ \\
\hline NGS & Low cost and short time to obtain massive sequence data & $\begin{array}{l}\text { Short read length } \\
\text { PCR-induced artifacts and bias } \\
\text { Requiring high-performance computer systems and } \\
\text { bioinformatics tools }\end{array}$ \\
\hline
\end{tabular}


터 얻은 많은 수의 염기서열을 단시간에 분석할 수 있게 되었다. 이들 기술을 이용해 미생물 다양성에 대한 정보 를 크게 넓혀가고 있다.

1) Denaturing Gradient Gel Electrophoresis (DGGE) 미생물 환경 생태 연구에 분자적 기술의 중요성은 1993년 Muyzer 등 (3)이 DGGE 기술을 이용해 복잡한 환경으로부터 미생물의 다양성을 분석하면서 시작되었다 고 할 수 있다. 이 방법은 다양한 미생물의 $16 \mathrm{~S} \mathrm{rRNA}$ 를 PCR로 증폭시킨 후 denaturing polyacrylamide 겔에 한꺼 번에 로딩하여 패턴을 분석함으로써 결과를 도출한다. 분 석은 전기영동 시 겔 내에 존재하는 denaturants (urea와 formamide)의 농도 구배에 따라 핵산의 이중나선 구조와 변성구조 즉, 염기서열이 가지는 $\mathrm{Tm}$ 값의 차이에 의해 핵산의 이동 속도가 달라 겔의 특정 위치에서 이동을 중단하면서 밴드를 형성하는 원리를 이용한 것이다. 미 생물 집단의 구성에 관한 좀더 구체적인 연구를 위해 기존에 알려져 있는 장내 우점종을 대상으로 종-특이적 (species-specific) primer를 제작하여 DGGE를 수행하기도 한다. 장내 미생물의 다양성을 알고자 DGGE 방법을 이 용할 때의 가장 큰 장점은 여러 샘플을 동시에 비교, 분 석할 수 있다는 점이다. 또한 시간의 흐름에 따른 복잡한 미생물 집단의 관계를 간단히 모니터링할 수 있다. 따라 서 $\mathrm{DGGE}$ 기술은 음식과 항생제 복용, 환경적인 변화 등 으로 인한 장내 미생물의 변화 양상을 모니터링하는 데 매우 유용한 기술이라고 할 수 있다 (4). 이렇게 미생물 집단의 분석이 용이한 장점이 있지만, 타 미생물 그룹에 비해 상대적으로 적은 양이 포함된 미생물 집단은 그만 큼 증폭 산물이 적기 때문에 검출에 제한이 있을 수 있 다. 또한 primer 합성 시 mismatch가 있어 검출에 오류가 있을 수 있으며, DNA 증폭 과정 시 오류 발생, 불분명한 melting domains 때문에 sequencing의 결과가 정확하지 못 하다는 단점도 동시에 존재한다.

\section{2) Quantitative $P C R(Q-P C R)$}

Q-PCR 기술은 표적 유전자만을 특이적으로 증폭함으 로써, 이 증폭량을 실시간으로 확인하는 기술이다. Q-PCR 의 원리는 PCR 증폭 시 형광물질(ethidium bromide, YOPRO-1, SYBR green 등)을 같이 넣어 주어 증폭시키면, 표적 유전자의 double strand DNA와 결합하여 강한 형광 빛을 발산한다. 여기서 나오는 형광강도를 검출하여 증폭
산물의 생성량을 실시간으로 측정할 수 있다. 특히 이 방 법은 빠른 검출 속도와 형광인자를 이용한 민감한 검출 방법이며, 높은 감도로 증폭이 가능하며, 오염률을 줄일 수 있는 장점이 있다. 샘플에 자신이 검출하고자 하는 표 적이 미량으로 존재하여 FISH나 일반 PCR로 검출하기 어려울 경우라도 Q-PCR 방법으로는 검출이 가능하다. 종 -특이적 primer를 제작하여 Q-PCR을 수행하면 소량의 변화를 보이는 종도 민감하게 검출이 가능하다. 이런 빠 르고 민감한 검출 방법은 기존의 배양이나 $\mathrm{PCR}$ 방법으 로 다루기 어려웠던 미생물 집단을 검출하기 위하여 사 용되었다. 그러나 PCR 당 가장 적합한 standard를 만들 어 비교해야만 하는 단점이 있다. 또한 standard는 target 과 유사한 조건에서 $\mathrm{PCR}$ 증폭이 일어나야 하며, 반응물 의 양을 정확히 알고 있어야 비교가 가능하다. 그리고 target과 standard와의 적정한 비율 범위를 맞추기 위해 여러 농도를 실험해야 한다는 번거로움이 있다.

\section{3) Fluorescence in situ hybridization (FISH)}

$\mathrm{FISH}$ 는 표적이 되는 $\mathrm{DNA}$ 와 $\mathrm{RNA}$ 에 형광물질인 fluorescein-isothiocyanate (FITC), tetramethyl-rhodamineisothiocyanate (TRITC), 또는 cyanine dye (Cy3TM, Cy5TM) 를 직접 붙여 검출하는 방법이다. 기존에 알려져 있는 염 기서열 정보를 토대로 15 23 nucleotides 길이의 probe를 제작하고, 이 probe의 5'-end에 형광 표지인자를 붙여 표 적 세포에 붙이면 형광현미경을 통해 육안으로 관찰이 가능하다. 이 방법은 인간의 장과 같이 복잡한 환경에서 특정 미생물 집단을 검출하기 위한 유용한 기술이며 (5), 배양 기술에서 벗어나 환경에서 직접 단일 세포의 동정 이 가능한 기술이다 (6). 이렇게 배양 방법에서 벗어나 환 경에서 직접 표적을 검출할 수 있다는 장점 때문에 probe 를 제작하여 간편하게 미생물 검출에 이용할 수 있다. 이렇게 제작한 하나의 probe는 oligonucleotide 제작 시 mismatch의 오류, 그리고 기존에 알려진 sequence 정보의 부정확성으로 인해 정확한 표적 세포만을 검출하기 어 렵다는 결론에 도달했다. 이를 극복하기 위하여 다양한 probe 제작에 관한 연구가 시작되었다. 특히 종-특이적 probe를 여러 개를 제작하여 경쟁적으로 사용할 경우에 는 하나의 probe를 사용하여 검출하는 것보다 훨씬 더 나 은 결과를 보이는 것이 입증되었고, 월등한 특이성을 보 여주었다 (7). 인간 장내에 우점을 형성하고 있다고 알 려져 있는 미생물(Bacteroides, Clostridium, Eubacterium, 
Streptococcus, Lactococcus)을 대상으로 6개의 genus-specific probe를 통해 장내에 형성되어 있는 각각의 미생물이 전 체 환경에서 얼마나 우점하고 있는지, 더 나아가 우점종 의 변화에 따라 건강 상태를 체크하는데 응용할 수도 있 고, 정상적인 장내 환경을 유지하기 위해 각 미생물들이 어떠한 역할을 하는지도 설명이 가능하게 되었다 (6). 하 지만 우리가 알고 있는 장내 미생물의 정보는 극히 일 부인데 반하여, 장내에 형성된 미생물은 매우 다양하고, 염기서열이 유사한 미생물들도 많이 존재하기 때문에 species level로 probe를 제작하여 모든 미생물을 검출하기 란 어려운 일일 것이다. 따라서 이것에 적합한 probe 제 작을 어떻게 하느냐가 관건이라고 할 수 있다.

\section{4) Flow cytometry}

Flow cytometry는 앞에서 설명한 FISH 기술과 같이 세 포에 직접 fluorescent tag을 붙이는 과정을 수반한다. 형 광물질을 붙인 세포를 특정 형광 검출기에 통과시키면서 특정 대상만을 검출하게 되는데, 기계에서 전자를 쏘면 형광의 유무에 따라 다른 전하를 띄게 함으로써 표적만 을 골라낼 수 있다. 이렇게 해서 전체 장내 미생물 집단 에서 특정 미생물의 수를 산정하는 것이 가능하다 (5). 건강한 사람의 분변 샘플을 flow cytometry를 이용하여 분석한 결과, 기존의 배양 방법으로는 검출되지 않았던 Ruminococcus obeum-like bacteria를 종-특이적 probe를 제 작하여 검출하였다 (8). $\mathrm{FISH}$ 의 방법으로 비교실험을 수 행한 결과, 유사한 결과를 도출함으로써 장내 미생물의 전체 그룹 중 표적 집단만을 검출하기 위한 방법으로 안정적이고 적합한 기술 방식으로 인정받고 있다. Flow cytometry는 다른 어떤 기술보다 빠르고 정확한 동정 능 력을 보이며 이러한 장점을 통해 사람에게서 보여지는 병원균을 빠른 시간 내에 보다 쉽게 검출할 수 있는 응 용 가능성이 있다.

3. 분자방법론에 의거한 대용량 동시 처리 기술(highthroughput technology)

DNA microarrays는 원래 1995년 유전자 발현 프로파일 링을 하기 위한 용도로 발달하였다 (9). 미생물 생태학에 서 메탄 순환, 미생물 다양성, 생물지구화학의 상관적 요소 등 다방면의 연구에 적용되었다 (10 13). 반면, pyrosequencing (Roche, Inc.), Illumina (Solexa, Inc.)와 SOLiD (Life Technologies, corp.)를 포함한 NGS 접근은 여러 시
료나 전사체로부터 수많은 DNA 단편을 분석할 때 비용 대비 효과적이고 신속하며 높은 염기서열분석을 제공한 다. 특히 pyrosequencing은 다른 NGS 기술들에 비해 read 의 길이가 상대적으로 길기 때문에 미생물 생태학 연구 에 적합하다. 따라서 NGS 기술 중에서도 pyrosequencing 이 가장 널리 사용되고 있다 (14). 오늘날 복잡한 미생물 군집의 분석을 위해 효과적이고 경제적인 면을 고려함 에 따라, DNA microarray는 NGS로 빠르게 대체되고 있 다. 일부 과학자들은 병원체 유전자형 검사 (15)와 인간 의 장내 미생물 군집 연구 (16)를 위해 pyrosequencing과 microarray를 동시에 사용하고 있지만, 추세는 과거 DNA microarray가 차지하고 있던 범위를 NGS가 광범위하게 대치하고 있다고 할 수 있다.

\section{1) Microarray}

최근 다루게 되는 유전자의 수와, 연구 범위가 넓어 지면서 high throughput 기술이 각광 받기 시작하였고, microarray를 이용한 기술이 각 분야에 적용되고 있다. 수백 개 내지 수천 개의 유전자(oligonucleotides, cDNA, genomic DNA)를 slide glass에 고정시키고, 알고자 하는 환경에서 추출한 DNA를 증폭시켜 형광물질을 붙인 후 유전자의 발현 변화를 측정하는 방법이다. Microarray는 최근 들어 장내 미생물 연구에도 적용되고 있다 $(17,18)$. 한 번의 실험으로 다량의 유전자 발현과 구조 정보를 쉽 게 알 수 있기 때문에, 장내와 같은 복잡한 환경 생태를 연구하기에 매우 유용하다 (17). 하지만 일부 유사한 염기 서열을 가지고 있는 종을 구별해 내기가 어려울 뿐 아니 라, 환경에서 추출한 DNA 증폭 시 편견(bias)이 일어나 hybridization 오류를 범할 수 있다.

2) 차세대 시퀀싱 기술(Next Generation Sequencing)

(1) SOLiD (Life Technologies corp., Carlsbad, CA, USA)

Sequencing by Oligonucleotide Ligation and Detection (SOLiD) sequencer는 아주 작은 비드(beads)에 DNA를 고정한 후 emulsion $\mathrm{PCR}$ 을 이용하여 증폭하는 방식을 취 한다. 2010년 말에 출시된 $\mathrm{SOLiD}^{\mathrm{TM}} 4$ system은 총 300 기 가 베이스의 염기서열을 12 16일 만에 얻을 수 있는데 DNA 절편 당 50 베이스의 매우 짧은 염기서열 정보를 얻게 된다.

자성을 띄는 작은 비드에 sequencing할 DNA가 결합되 
는데 하나의 비드에 하나의 DNA만 결합하게 된다. 이때 비드에 생긴 clonal이 늘어나고 emulsion PCR을 통해 비드에 결합되어 있는 DNA 절편이 증폭하게 된다. 증 폭된 DNA 비드를 flow cell에 붙여서 sequencing을 하 게 되는데, 이 때 한 flow cell 당 1 18개의 개별 시료를 sequencing 할 수 있으며, 한 번의 작동으로 최대 1,536 개 의 복합 시료를 분석할 수 있다. 다른 NGS보다 높은 정 확도를 갖기 때문에 single-nucleotide polymorphism (SNP) 나 삽입, 결실 등의 변이 정보를 확인하는데 많이 사용 되며, 미생물의 whole genome sequencing에 사용되기도 한다.

(2) Illumina (Solexa, Inc., Hayward, CA, USA)

Illumina는 DNA를 짧은 단편으로 만든 후 flow cell에 접합할 수 있는 adapter를 붙인다. 그 뒤 adapter가 붙은 DNA를 flow cell에 뿌려 bridge amplification을 통해 DNA 증폭을 한 후 sequencing을 하게 된다. Hiseq 2000은 한번 의 작동에 8 일이 소요된다. 그리고 한번에 8 개의 샘플 을 동시에 sequencing 할 수 있으며, NGS 중 가장 저렴한 비용으로 운용할 수 있는 특징이 있다. 또한 100 base 정 도의 DNA sequencing이 가능하며 한번에 150 기가의 염 기서열을 얻을 수 있다. 각 read의 길이가 짧지만 최종적 으로 산출되는 염기서열 길이의 합이 크기 때문에 whole genome sequencing이 가능하다. 이와 같은 장점 때문에 장 내 미생물 분석에 사용되고 있기도 하다. 2010년 Nature 에 게재된 MetHIT (Metagenomics of the Human Intestinal Tract) 프로젝트는 Illumina를 이용하여 얻은 결과이다. 즉, 이를 이용해서 인체에 존재하는 3 백만개 이상의 미생물 유래 유전자들을 선별하였고, 그 결과 $1,000 ~ 1,150$ 여 종 의 미생물이 항상 존재하며, 이 중 160 여 종의 장내 미생 물이 필수 미생물임을 증명하였다 (19).

(3) Pyrosequencing (Roche, Inc., Branford, CT, USA)

Roche의 Genome Sequencer FLX (pyrosequencing)는 환 경 및 장내 미생물의 metagenome 분석으로 광범위하게 사용되는 최신 방법 중 하나이다. Sequencing-by-synthesis 방법을 통해 증폭된 PCR product로부터 고도병렬 DNA 염기서열 reads (massive parallel DNA sequence reads)을 만들어 낸다. Pyrosequencing은 SOLiD와 비슷한 방법인 bead에 adapter-ligated DNA 절편을 붙여 증폭하는 방법 은 비슷하지만 각 염기를 탐지하는 방법에 차이가 있다. Pyrosequencing에서 얻어지는 데이터는 뉴클레오티드가
결합할 때 방출되는 pyrophosphate로부터 빛을 검출하는 원리로 산출된다. Pyrosequencing 방법은 다른 NGS보다 base 당 분석비용이 더 비싸고 더 많은 초기물질이 필요 하지만, 최근, 새로운 GS FLX Titanium series (Roche, USA) 로 인해, de novo 염기서열분석에 적합한 더 긴 read의 길이를 얻을 수 있다. 한번 실행하는 동안 100 만 reads 이상의 각 DNA 절편당 400 bases의 서열분석이 가능하 여 high-throughput sequencing 도구로 운용되었다. 또한 샘플을 구분하기 위한 barcode의 이용으로 많은 시료를 한번에 sequencing이 가능해졌으며, 이는 표적 군집의 고 도의 시간적, 공간적 다양성에 의해 많은 양의 시료 분석 이 요구될 때 유용하다.

장내 미생물 군집 분석에 있어서 PCR은 pyrosequencing 에 앞서 수행되는 단계이다. PCR 결과 생기는 chimera, mutations, heteroduplex molecules 등의 형성 (20)이나 PCR 주형 대 PCR 산물의 비대칭적인 비율 (21) 같이 PCR에 의한 오류는 미생물 군집의 다양성을 과도 또는 과소 측 정하는 결과를 낳을 수 있다. 하지만 이런 오류는 RDP II, Nellerophon (22) 등의 키메라 확인 프로그램이나 PCR의 cycle 수 제한 등으로 다소 줄일 수 있다. Pyrosequencing 은 이런 단점이 있음에도 ultra-deep sequencing이 가능하 기 때문에 분변 시료에서 지금까지 밝혀지지 않은 분류 군의 장내 미생물을 동정할 수 있게 되었다. 동시에 이 방법은 다양한 환경에 적용되고 있으며 $(14,16)$, genome sequencing에 이용되기도 한다 (23). 예를 들어 Jeffrey Gorden의 연구진은 Genome Sequencer FLX을 이용하여 metagenome 분석을 하였다. 그 결과 한 어머니에게 출생 한 쌍둥이들은 유전적으로 무관한 타인들 보다는 장내 박테리아 군집의 유사성을 보였다. 그렇지만 같은 박테리 아 군집을 갖는 어머니와 쌍둥이라고 하더라도 장내 바 이러스 군집이 서로 다르며, 시간이 지나도 변하지 않는 다는 것을 발견하여 metagenome 연구에 pyrosequencing 이 대단히 효과적 임을 증명하였다 (24).

이와 같이 NGS를 이용한 장내 미생물에 대한 분석은 지금까지 분석의 한계로 인해 알 수 없었던 미생물의 기 능을 설명하는데 한 발자국 멀리 볼 수 있는 시각을 주 고 있다.

\section{결 론}

분자적 접근 방법을 이용한 미생물 연구에서 몇몇 환경 
시료는 깊이 있게 연구되어야만 한다. 이 연구를 위해 오늘날 NGS 기술은 큰 잠재력을 갖고 있다. 과거에 microarry는 미생물 연구의 많은 부분을 차지하는 연구 방법이었으나, 오늘날 그 자리를 현재의 NGS 기술로 대 치되고 있는 실정이다. 그렇지만 이 두 가지 방법이 양 자택일의 기술로 생각할 수 있지만, 미생물 생태학에 있 어서는 서로 달리 적용할 수 있는 뚜렷한 상호보완적 특 징을 갖고 있다. 즉, microarray는 표적 염기서열의 일반 적인 연구에 효과적인 연구 방법이다. 반면 NGS data는 microarray probe sets 설계에 이용될 수 있어 미생물 유전 자 다양성의 이해를 가능케 한다.

최근 NimbleGen (Roche Nimblegen, Inc., Madison, WI, $\mathrm{USA}$ )은 probe hybridization 되는 표적 DNA 절편들이 염 기서열분석과 같은 하위 분석에 사용될 수 있는 'sequence capture array'를 개발하였다. 이런 결합적 접근은 환경 미 생물 군집의 상세한 검사를 가능하게 하였고, 주어진 환 경 안에서 시간, 공간, 기능적 규모의 커버가 필요한 많 은 시료의 깊이 있는 분석을 통해 미생물과 그것의 환경 사이의 관계를 이해하는데 많은 기여를 할 수 있을 것 이다.

\section{참 고 문 헌}

1) Whitman WB, Coleman DC, Wiebe WJ. Prokaryotes: the unseen majority. Proc Natl Acad Sci U S A 1998;95:6578-83.

2) Amann RI, Binder BJ, Olson RJ, Chisholm SW, Devereux R, Stahl DA. Combination of 16S rRNA-targeted oligonucleotide probes with flow cytometry for analyzing mixed microbial populations. Appl Environ Microbiol 1990;56:1919-25.

3) Muyzer G, de Waal EC, Uitterlinden AG. Profiling of complex microbial populations by denaturing gradient gel electrophoresis analysis of polymerase chain reaction-amplified genes coding for 16S rRNA. Appl Environ Microbiol 1993;59:695 -700 .

4) Favier CF, de Vos WM, Akkermans AD. Development of bacterial and bifidobacterial communities in feces of newborn babies. Anaerobe 2003;9:219-29.

5) Namsolleck P, Thiel R, Lawson P, Holmstrom K, Rajilic M, Vaughan EE, et al. Molecular methods for the analysis of gut microbiota. Microb Ecol Health Dis 2004;16:71-85.

6) Franks AH, Harmsen HJ, Raangs GC, Jansen GJ, Schut F, Welling GW. Variations of bacterial populations in human feces measured by fluorescent in situ hybridization with group-specific 16S rRNA-targeted oligonucleotide probes. Appl Environ Microbiol 1998;64:3336-45.

7) Lay C, Sutren M, Rochet V, Saunier K, Dore J, Rigottier-Gois L. Design and validation of $16 \mathrm{~S}$ rRNA probes to enumerate members of the Clostridium leptum subgroup in human faecal microbiota. Environ Microbiol 2005;7:933-46.

8) Zoetendal EG, Ben-Amor K, Harmsen HJ, Schut F, Akkermans AD, de Vos WM. Quantification of uncultured Ruminococcus obeum-like bacteria in human fecal samples by fluorescent in situ hybridization and flow cytometry using 16S rRNAtargeted probes. Appl Environ Microbiol 2002;68:4225-32.

9) Schena M, Shalon D, Davis RW, Brown PO. Quantitative monitoring of gene expression patterns with a complementary DNA microarray. Science 1995;270:467-70.

10) Bodrossy L, Sessitsch A. Oligonucleotide microarrays in microbial diagnostics. Curr Opin Microbiol 2004;7:245-54.

11) Zhou J. Microarrays for bacterial detection and microbial community analysis. Curr Opin Microbiol 2003;6:288-94.

12) Bae JW, Park YH. Homogeneous versus heterogeneous probes for microbial ecological microarrays. Trends Biotechnol 2006; 24:318-23.

13) Wilson KH, Wilson WJ, Radosevich JL, DeSantis TZ, Viswanathan VS, Kuczmarski TA, et al. High-density microarray of small-subunit ribosomal DNA probes. Appl Environ Microbiol 2002;68:2535-41.

14) Lazarevic V, Whiteson K, Huse S, Hernandez D, Farinelli L, Osterås M, et al. Metagenomic study of the oral microbiota by Illumina high-throughput sequencing. J Microbiol Methods 2009;79:266-71.

15) Akhras MS, Thiyagarajan S, Villablanca AC, Davis RW, Nyren P, Pourmand N. PathogenMip assay: a multiplex pathogen detection assay. PLoS ONE 2007;2:e223.

16) Claesson MJ, O'Sullivan O, Wang Q, Nikkila J, Marchesi JR, Smidt $\mathrm{H}$, et al. Comparative analysis of pyrosequencing and a phylogenetic microarray for exploring microbial community structures in the human distal intestine. PLoS ONE 2009;4: e6669.

17) Quince C, Lanzen A, Curtis TP, Davenport RJ, Hall N, Head $\mathrm{IM}$, et al. Accurate determination of microbial diversity from 454 pyrosequencing data. Nat Methods 2009;6:639-41.

18) Gomez-Alvarez V, Teal TK, Schmidt TM. Systematic artifacts in metagenomes from complex microbial communities. ISME J 2009;3:1314-7. 
19) Qin J, Li R, Raes J, Arumugam M, Burgdorf KS, Manichanh $\mathrm{C}$, et al. A human gut microbial gene catalogue established by metagenomic sequencing. Nature 2010;464:59-65.

20) Qiu X, Wu L, Huang H, McDonel PE, Palumbo AV, Tiedje $\mathrm{JM}$, et al. Evaluation of PCR-generated chimeras, mutations, and heteroduplexes with 16S rRNA gene-based cloning. Appl Environ Microbiol 2001;67:880-7.

21) Polz MF, Cavanaugh CM. Bias in template-to-product ratios in multitemplate PCR. Appl Environ Microbiol 1998;64:3724 -30 .
22) Huber T, Faulkner G, Hugenholtz P. Bellerophon: a program to detect chimeric sequences in multiple sequence alignments. Bioinformatics 2004;20:2317-9.

23) Jeong H, Barbe V, Lee CH, Vallenet D, Yu DS, Choi SH, et al Genome sequences of Escherichia coli B strains REL606 and BL21(DE3). J Mol Biol 2009;394:644-52.

24) Reyes A, Haynes M, Hanson N, Angly FE, Heath AC, Rohwer $\mathrm{F}$, et al. Viruses in the faecal microbiota of monozygotic twins and their mothers. Nature 2010;466:334-8. 